\section{DIARY}

\section{NOVEMBER 2009}

British Academy of Cosmetic

Dentistry Study Club:

Predictable resin retained bridgework

Date: 26 November 2009

Venue: James Hull Associates, Birmingham

Tel: 02082418526

Email:suzy@bacd.com

Premier Symposium 2009

Date: 28 November 2009

Venue: Kings College London

Tel: 02073991339

Email: sarah.garry@mps.org.uk

www.dentalprotection.org

\section{JANUARY 2010}

British Academy of Cosmetic Dentistry Study Club: Impression free dentistry: are we there yet?

Date: 26 January 2010

Venue: British Dental Association, London www.bacd.com

\section{FEBRUARY 2010}

The National Association of Prison Dentistry UK Annual Conference

Date: 5 February 2010

Venue: Birmingham Botanical

Gardens \& Glasshouses

www.napduk.org

Dental Forum 2010

Date: 4-6 February 2010

Venue: Vincennes, The Parc Floral, Paris

www.dentalforum2010.com

\section{CONTRACT STILL UNSUITABLE}

Reacting to the publication by the Department of Health of the final version of the 'PDS+' agreement developed for the current round of dental access procurement this month, the BDA's General Dental Practice Committee said the complex contracts for dental access funding make them risky and inappropriate for dental practice, despite some changes being made. John Milne, Chair of GDPC, said the BDA advised dentists to think very carefully and seek advice before taking on one of these contracts.

\title{
VIRTUAL LABORATORY LAUNCHED
}

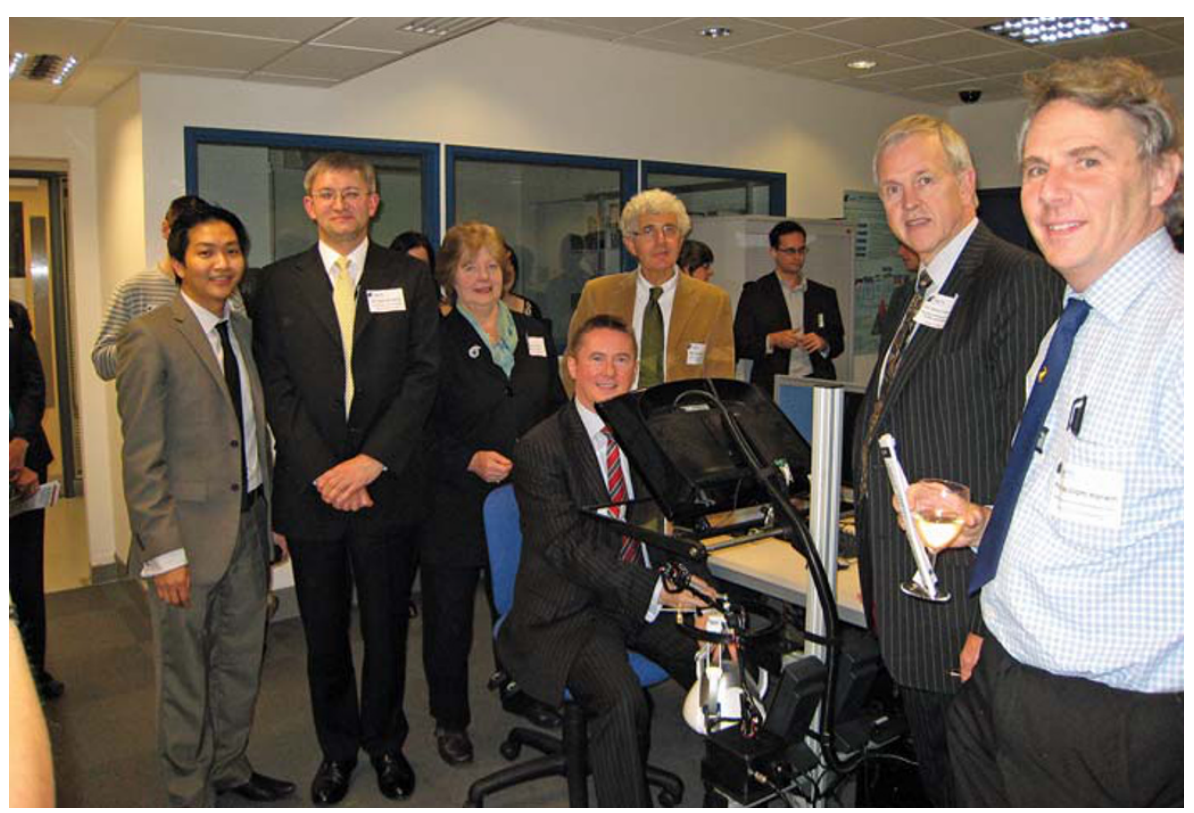

Left to right: Dr Jonathan P. San Diego (Senior Research Officer and Project Manager, hapTEL, KCL), Dr Mark Woolford, (Director of Education, Dental Institute, KCL), Professor Margaret Cox (Director, hapTEL, KCL), Dr Barry Quinn (Dental Institute, KCL), Professor Richard Noss (Director, London Knowledge Lab \& TEL Programme), Professor Stephen Challacombe (Vice Dean, Dental Institute, KCL) and Professor William Harwin (Head, Interactive Systems Research Group (UoR) Strand 1 Co-ordinator)

King's College London (KCL) Dental Institute has recently launched a new hapTEL (haptic technology enhanced learning) virtual dental lab.

Virtual reality haptic systems allow human touch and interaction with the external environment. The hapTEL project is a $£ 1.5$ million four-year project funded jointly by the Engineering and Physical Sciences Research Council (EPSRC) and the Economic and Social Research Council (ESRC) involving KCL, Reading and Birmingham City Universities.

The project is one of eight large technology enhanced learning (TEL) projects whose overall research goal is to improve the quality of formal and informal learning and to make accessible forms of knowledge that would not have been possible without these new virtual systems.

The four themes of the TEL programme are personalisation, flexibility, productivity and inclusion. The overall aim is to develop and evaluate haptic and synthetic online devices, which can be used by a range of dental students and professionals. The project involves working with a wide range of students who are either studying to become dentists or dental care professionals or improving their professional practice.
Professor William Harwin, Lead of the Technical Development team from the University of Reading, explained, 'The hapTEL workstation will bring new methods of integrating advanced visualisation tools that include the three primary senses, (vision, touch and sound) to the area of learning complex skills. Dental education is a great test for these ideas since it requires sophisticated skills that are coordinated with deep knowledge.'

The project is part of the TLRP Technology Enhanced Learning Programme and directed by Professor Richard Noss of the London Knowledge Lab. As part of the opening ceremony, Professor Richard Noss and Professor Stephen Challacombe led the guests in cutting the ribbon to mark its opening.

Nairn Wilson, Dean and Head of King's College London Dental Institute, commented, 'The Dental Institute is delighted to be the Centre leading the integration of virtual reality haptic systems in undergraduate dental education. This innovative work compliments the e-learning initiatives which have given the Institute international standing in the field of flexible learning. The hapTEL project is anticipated to revolutionise core aspects of dental education. 